\title{
DYNAMIC UPLIFT DURING SLAB FLATTENING
}

\author{
${ }^{1,2}$ Federico M. Dávila and ${ }^{1}$ Carolina Lithgow-Bertelloni \\ ${ }^{1}$ Dept. Earth Sciences, University College London, Gower Street, London WC1E 6BT, UK \\ 2CICTERRA-CONICET-Universidad Nacional de Córdoba, Córdoba 5016, Argentina. fmdavila@efn.uncor.edu
}

\begin{abstract}
Subduction exerts a strong control on surface topography and is the main cause of large vertical motions in continents, including past events of large-scale marine flooding and tilting. The mechanism is dynamic deflection: the sinking of dense subducted lithosphere gives rise to stresses that directly pull down the surface. Here we show that subduction does not always lead to downward deflections of the Earth's surface. Subduction of young lithosphere at shallow angles (flat subduction) leaves it neutrally or even positively buoyant with respect to underlying mantle because the lithosphere is relatively warm compared with older lithosphere, and because the thickened and hence drier oceanic crust does not undergo the transformation of basalt to denser eclogite. Accounting for neutrally buoyant flat segments along with large variations in slab morphology in the South American subduction zone explains alongstrike and temporal changes in dynamic topography observed in the geologic record since the beginning of the Cenozoic. Our results show that the transition from normal subduction to slab flattening generates dynamic uplift, preventing back-arc marine flooding.
\end{abstract}

\section{Introduction}

South America is an ideal natural laboratory to study the influence of subduction morphology on dynamic topography. The present-day geometry of subduction (>3000 km length) changes radically 
along strike (Booker et al., 2004; Gans et al., 2011) and includes two regions with flat subduction, each associated with the subduction of aseismic ridges with over thickened crust (Nazca and Juan Fernandez ridges, Fig. 1). The location and extent of flat subduction segments has varied with time (Kay and Mpodozis, 2002), allowing us to relate the time history of dynamic topography as revealed in foreland basins to secular variation in subduction zone morphology.

Global and regional models of present-day South American dynamic topography and its temporal evolution (Lithgow-Bertelloni and Gurnis, 1997; Lithgow-Bertelloni and Richards, 1998; Shephard et al., 2010, 2012) disagree with the geologic record (Jordan and Allmendinger, 1986; Espurt et al., 2007; Dávila et al., 2010, 2012; Devlin et al., 2012). Though the temporal evolution in both Lithgow-Bertelloni and Gurnis (1997) and Shephard et al. (2010) imply differential uplift and subsidence from the early Cenozoic to the present, the amplitudes and locations differ substantially with respect to the geologic record and imply different dynamical mechanisms. Shephard et al. (2010) predict a large subsiding area 30-40 My that occupies almost all of northern South America including the Andes and Andean foreland that gradually uplifts dynamically as the slab migrates and steepens. The models predict subsidence in geographic disagreement with the location of the northern and southern Amazonian basins and in detail with topographic observations of uplift (e.g., Espurt et al., 2007 in Peru or Dávila et al., 2012 in Argentina). The dynamical evolution of the slab is also in stark contrast with the present-day Nazca slab morphology (Fig. 1b). At 60 My an enormous mass of flat cold material ('slab') occupies the entire upper mantle evolving to a more steeply dipping slab for the present-day. The slab evolution is not a short-coming of these sophisticated state-of-the-art adjoint models, but rather stems from known limitations for the backwards advection of initial conditions (Bello et al., 2014) choices regarding slab and plate boundary rheology and an initial buoyancy source derived from global tomographic models whose wavelengths, inherent damping and resolution do not capture crucial aspects of slab morphology and density structure. The latter include along- 
strike variations in subduction angle and density structure due to age variations and thicker than normal crust. These large age variations are important for elevations within and away from the mountain belt as highlighted by Capitanio et al. (2011). Older (cooler, denser) slabs lead to faster subduction and more vigorous flow in the mantle wedge. In turn the flow exerts stronger shear tractions at the base of the overriding plate leading to crustal thickening and higher elevations.

Along-strike variations in subduction morphology (e.g., Fig. 1) are apparent in South America's foreland surface topography. In the southern part of the Peruvian foreland $\left(10^{\circ} \mathrm{S}\right)$ up to $>700 \mathrm{~km}$ from the trench we find the Fitzcarrald arch, an elevated long-wavelength bulge (Espurt et al., 2007; Fig. 1b). This Arch overlies the Peru flat slab and lies eastward from the easternmost Andean thrusts, where no thrusting or folding has been documented (Espurt et al., 2007). This segment also exposes a highelevation intermontane broken foreland system (Devlin et al., 2012) (PBF in Fig. 1b). Further south, above the Argentine-Chilean flat-slab segment at $30-32^{\circ} \mathrm{S}$, the distal foreland $(>600 \mathrm{~km}$ eastward) also shows a high-elevation foreland system (Fig. 1b): the Sierras Pampeanas broken foreland (often used as a modern analogue for the US Laramide, Jordan and Allmendinger, 1986). The Sierras Pampeanas are isostatically uncompensated and have associated high-elevation depocenters $>1 \mathrm{~km}$ above sea level (Dávila et al., 2012). These features date to the latest Miocene-Pliocene, coeval with the advent of flat subduction (Ramos, 2009). Flat subduction is also often associated with tectonic deformation like lithospheric thickening and basement thrusting, present in the Sierras Pampeanas but not on the Fitzcarrald Arch.

Here we first produce high-resolution models that capture the morphology and density structure of the Nazca slab (Fig 1b) and then use them to predict the surface dynamic topography produced by the induced viscous flow (Fig. 2). We show that flat subduction has a decisive influence on the sign, amplitude, and pattern of dynamic topography. We suggest that the change from 'typical' subduction to slab flattening leads to dynamic uplift rather than subsidence (Fig. 3). Together with crustal deformation (Dávila et al., 2010; Dávila and Lithgow-Bertelloni, 2013) and lithospheric thickness 
changes due to, for example delamination (Garzione et al., 2008), the dynamic uplift determines today's total topography (Fig. 3) as suggested by observed deficits and excesses in residual topography (Steinberger, 2007). We compare our results with two independent sources, a regional residual topography model and structural reconstruction of the regional paleosol marker of the Los Llanos Formation, which developed on a flattened surface across the Miocene foreland (Fig 2 bottom right panel).

\section{Methodology}

We assume that the dominant driving force for mantle flow and the resulting surface dynamic topography is subducted density heterogeneity. Subducted heterogeneity, in an otherwise neutrally buoyant mantle, excites instantaneous flow that produces surface deformation, plate motions, and geoid in good agreement with a wealth of observations as shown in a number of previous studies (e.g. Lithgow-Bertelloni and Richards, 1998). An important advantage of focusing on subducted heterogeneity is that slab morphology for South America is known in detail.

Our present-day Nazca slab model (Fig 1 bottom panel) is considered as representative of the slab geometry over the Neogene ( 20 My to present), and derived from constraints on slab morphology from regional seismic and magneto-telluric surveys (Gutscher, 2002; Booker et al., 2004; Gans et al., 2011). This episode temporally matches the formation of the foreland landscapes in Peru and Argentina (Espurt et al., 2007; Dávila et al., 2012) described above. Some uncertainty exists over the exact timing of the arrival of the flat slab, which could be as late as 12-11 Ma (Ramos and Folguera, 2009) though the vas majority of the literature supports a date closer to 20 Ma (Dávila et al., 2004). The subduction angles vary along strike from flat $\left(0^{\circ}\right)$ to a typical $\left(30^{\circ}\right)$ for South America and the density contrasts $(\Delta \rho)$ of the slab (with respect to the mantle) are controlled by the slab age, the inferred crustal thickness and the Benioff zone geometry (Fig. 1 bottom panel). The net buoyancy 
difference between normal and oceanic lithosphere with overthickened crust is largely determined by the thickness of the basaltic layer and that of the depleted harzburgitic mantle (c.f. Cembrano et al. 2007, Arrial and Billen, 2013). From the crustal thicknesses and compositions across the Argentine and Peruvian flat-slab segments ( $20 \mathrm{~km}$, Gans et al., 2011; Bishop et al., 2013) and the Nazca ridge offshore ( 17-18 km, Woods and Okal, 1994) and the self-consistent thermodynamics of Stixrude and Lithgow-Bertelloni (2011), we estimated an integrated density contrast across the modern flat slab of $\sim 10 \mathrm{~kg} / \mathrm{m}^{3}$ less than ambient mantle (c.f. Appendix). To be conservative we modeled flat-slab segments with neutral buoyancy $\Delta \rho=0$ (Fig. 1, see Appendix for further detail), though we also show results for the former. Typical density contrasts for subducting slabs are as high as $\mathbf{8 0}$ $\mathrm{kg} / \mathrm{m}^{3}$ greater than ambient mantle. Our highest density contrast is $50 \mathrm{~kg} / \mathrm{m}^{3}$ for the oldest subducting lithosphere. The resulting Nazca slabs have a resolution of $1^{\circ} \times 1^{\circ}$, considerably higher than previous models, though density and geometric variations occur on average every $400-500$ km (Fig. 1 bottom panel). The new high-resolution Nazca slabs are embedded in an existing global slab model (Lithgow-Bertelloni and Richards, 1998) and expanded to spherical harmonic degree and order 80. We compute the instantaneous flow and resulting dynamic topography (c.f Appendix for technical details) induced by these density fields in a spherical shell to degree and order 50 for a mantle with a radially layered viscosity that best matches the observed geoid (Lithgow-Bertelloni and Richards, 1998) (Appendix, Fig. Ap2). The density and flow field expansions correspond to wavelengths between $500-800 \mathrm{~km}$, comparable to the variations in slab morphology and density.

To explore the time variation of dynamic topography, we also constructed a Paleocene-Early Miocene Nazca slab model (from here on referred to as the Paleogene model), in which the slab dips $\sim 30^{\circ}$ eastward homogeneously along strike, representative of the geometry of the Farallon and early Nazca slabs (Mpodozis and Ramos, 1989). Tectonic and volcanic arc reconstructions (Kay and 
Mpodozis, 2002) suggest that prior to the Paleocene subduction was sub-vertical, likely a Mariana-type system (Mpodozis and Ramos, 1989).

We also calculated the dynamic topography induced by buoyancy inferred from a global shear wave velocity model (S40RTS Ritsema et al., 2011) for comparison (Fig. Ap1) with our present-day residual topography. For validation, we compute the local residual topography along the Argentine flat slab segment at $\sim 31^{\circ} \mathrm{S}$ and compare it to our present-day dynamic topography prediction (Fig. 5a). Residual topography is the topography remaining after accounting for the isostatic contribution of crustal and lithospheric structure. The isostatic topography was calculated using crustal thicknesses and densities (Table 1 Appendix) for the continent from Gans et al. (2006) for three regions (High Andes, Sierras Pampeanas and Pampas). Additionally, the lithospheric mantle is divided into depleted and enriched regions whose thicknesses depend on the thickness of the lower crust, where present, following our recently published lithospheric structure model (TDL) described in the Appendix of Naliboff et al., 2012. The isostatic elevations are calculated with respect to an oceanic reference column with a compensation depth of either 100 or $200 \mathrm{~km}$, depending on whether we assume the flat segment contributes to the isostatic support or not (bands in Fig. 5a). Seismic studies (Gans et al., 2011 and Bishop et al., 2013) show that the flat segments completely underlie the continental lithosphere with no intervening asthenosphere, hence it is conceivable and even likely that the flat oceanic lithosphere is contributing isostatic support. Densities and thicknesses for crust, depleted and enriched mantle are listed in Table 1 of the Appendix. We also compare our results to profiles from previous global estimates of residual topography (Fig. 4) by Flament et al. (2013) and Naliboff et al. (2012).

Results 
Our results demonstrate that the morphology and density structure of the slab have a strong effect on the pattern and amplitude of dynamic topography as evident in the top two panels of Fig. 2 and in agreement with our previous results (Dávila et al., 2010; Dávila and Lithgow-Bertelloni, 2013; Eakin et al., 2014). The present-day model shows not only a migration of the topographic wave to the east with respect to the Paleogene model, especially along flat segments, but also a strong reduction in amplitude (Dávila and Lithgow-Bertelloni, 2013, Fig. 3). The latter is the direct result of the neutral density contrast over horizontal segments (Fig. 1 bottom panel), which simulates the expected buoyancy of the oceanic lithosphere where aseismic ridges with thickened crust have been previously subducted. The amplitude of dynamic topography is reduced by as much as a $100 \mathrm{~m}$ in Peru compared to the Paleogene model, and not recorded at all in Argentina (Fig. 2 middle planel). In the present-day model we observe 100 m downwarp (Fig. 2) only at the slab leading edge $>800 \mathrm{~km}$ away from the trench in Argentina and on the order of $\sim 400 \mathrm{~m}$ in Peru, in agreement with stratigraphic observations within the Argentine Pampas (Dávila et al., 2010; Gimenez et al., 2011) and the Amazonian basins (Eakin et al., 2014). The temporal uplift coincident with the arrival of neutrally buoyant flat segments agrees with our previous work (Dávila et al., 2010; Dávila and Lithgow-Bertelloni, 2013 and Eakin et al., 2014). However, in these new models the total subsidence is minimal compared to our previous models. This is the result of embedding our regional model in a global slab model with largely subvertical slabs. In particular for South America, the global slab model does not contain enough lower mantle buoyancy related to slabs (compared to tomography) and induces large amounts of upwelling return flow which overwhelms the subsidence signal at the leading edge. The local differences with Eakin et al. (2014) are due to differences in the morphology of the slab in Perú obtained from recent seismicity and the model of Gutscher et al. (2002) as well as the assignment of ages and hence density contrasts of the subducting lithosphere.

Our predicted changes in dynamic topography do not reproduce the dynamic subsidence along NW South America associated with the Miocene Pebas mega-wetland in Shephard et al. 
(2010), a point we expand upon below. Our dynamic signal is close to neutral (Fig. 5). We think that flexural loading in this area given the Andes crustal building is however a very important contribution to the subsidence though it does not explain the full spatial and temporal extent of the Pebas (Sacek, 2014).

\section{Discussion}

Residual topography over flat slabs

Direct observations of dynamic topography are not possible and any estimates are necessarily inferences. The dynamic signals are masked by uncompensated tectonics and flexural contributions to total topography. A good proxy for dynamic topography is the residual topography, understood as the non-isostatic topographic contribution of the observed topography (Steinberger, 2007; Flament et al., 2013). A common practice in these studies is to compute isostatic topography from a given crustal and lithospheric structure, which can then be used to compute residual topography (see compilation in Flament et al., 2013 and references therein). The difficulty lies not only in the uncertainty in crustal and lithospheric mantle structure (Lestunff and Ricard, 1995; Naliboff et al., 2012) but in fundamental misunderstandings as to what part of the lithosphere participates in convection. For example, it is not uncommon to compute residual topography only due to crustal structure (Steinberger, 2007). It is also typical to ignore the flexural contribution to topography because most studies focus on the global scales at wavelengths no smaller than the width of the continent. For tectonically active areas with broad deformation like the Andes, ignoring flexural contributions is perilous. The result at the regional level is residual estimates that can differ by $100 \%$ in amplitude and sign (Fig. 4).

Comparison along $31{ }^{\circ} \mathrm{S}$ of the residual topography from the local profile, Flament et al. (2013), TDL (Naliboff et al., 2012) and predicted dynamic topography from our slab models and S40RTS are shown in Fig. 5a and illustrates the point above. Our predicted present-day dynamic 
topography at $31^{\circ} \mathrm{S}$ is compatible with residual topography estimates (Fig. 5a) but large uncertainties in the estimates are evident. Differences arise within South America depending on the assumptions about crustal and lithospheric structure in the Andes (Fig. 4). The dynamic topography calculated using S40RTS differs from our present-day model in detail. However, when accounting for differences in length scale (harmonic degree 50 vs 40), the disagreement between the tomographic structure and present-day seismicity, lateral resolution, damping and other issues inherent to tomographic inversions, one can visualize the tomographic model as a smoothed, laterally shifted version of the present-day slab model. It is also likely that the better visual agreement between the predicted dynamic topography from S40RTS (Fig. Ap1) and some of the residual topography models of Fig. 4 stems from the presence of buoyancy in the upper and lower mantle unaccounted for in the global slab model. Over the actual flat segments however correlation is very poor (Fig. 5a). Our predictions for neutrally buoyant slabs across the flat slab area and up to $\sim 800 \mathrm{~km}$ from the trench show a good fit, within the range of existing residual topography estimates. Flat slabs whose buoyancy is purely thermal, such as the S40RTS curves (whether one removes 140 or $290 \mathrm{~km}$ of possible chemical signals), induce much too large negative dynamic topography as in Shephard et al. (2010) or Lithgow-Bertelloni and Gurnis (1997) with peak to peak amplitudes of nearly $3 \mathrm{~km}$. However, at distances far from the flat segment and leading edge, influenced by subducted heterogeneity in the lower mantle, our slab model does not predicted enough negative dynamic topography. This is a shortcoming of our global slab model based on nearly subvertical slabs.

Our preferred present-day dynamic topography (buoyant and neutral density contrasts with respect to the surrounding mantle, closer dashed and black solid lines, respectively) lies within the range of residual topography calculations for South America (gray band) filtered to similar wavelengths (degree and order 20). Instead, a prediction that accounts for geometry but without neutral buoyancy (more separated black dashed line) lies outside existing residual estimates. To focus further 
on the results above the flat segments, we use a more detailed regional residual topography (Table 1 Appendix) along the Chilean-Argentine flat-slab segment based on the local continental lithospheric structure. The local profile, constructed at much shorter wavelengths, suggests much larger positive residual topography over the flat-slab segment, perhaps indicating that the segment is more strongly buoyant. However, the elevations can vary by more than a factor of depending on the exact thickness of lower crust, depleted and enriched mantle and reltively small variations in density. The results are similar in the Peruvian flat segment (Eakin et al., 2014).

Geophysical observations are also consistent with our conclusions. Free-air gravity anomalies are considered as proxy for the spatial distribution of dynamic topography (Winterbourne et al., 2009). Bouguer anomalies that use isostatic models in west-central Argentina are strongly positive (i.e.overcompensated, Martinez and Gimenez, 2003), implying dynamic support consistent with uplift. There have been no major changes in lithospheric structure and flexural loads due to mountain building in the foreland areas to the east of the High Andes (Dávila et al., 2005) that would alter the isostatically supported topography or create uncompensated tectonic relief. Shortening has been minimal $(<\mathbf{5 \%})$ but elevations are over $5 \mathrm{~km}$ (Dávila et al., 2005 and references therein), therefore, we can safely assume that the residual topography today reflects not only the presence of a neutral or buoyant slab, but also the change in dynamic topography from the arrival of the flat segment. This is evident in Figure 5b, where most if not all of the positive residual topography across the foreland can be explained by the predicted dynamic uplift.

\section{Slab flattening and dynamic topography}

Slab flattening is likely the major driving mechanism in the generation of relief within the distal Andean foreland right above the flat segment. Topography over steeply plunging subduction segments in the Present-day model does not differ significantly from the Paleogene model. This topographic 
evolution, especially over flat slabs, has a strong influence on the change of dynamic topography, which is, in turn, the vertical displacement that we can observe and measure in the geological record.

The change of dynamic topography (Present-Paleogene) as a result of slab flattening produces dynamic uplift (Fig. 3) that explains diverse geological and geophysical observations over the Cenozoic, which we detail below. A good strategy for assessing dynamic uplift and subsidence is to find regions where tectonic and flexural contributions are minimal such as stable continents (e.g., Lithgow-Bertelloni and Gurnis, 1997). We have previously shown that in the tectonically stable Pampas and Amazonian Plain, anomalous subsidence at the leading edge of the subducting slabs $(>800$ km from the trench; Dávila et al., 2010; Eakin et al., 2014) is explained by temporal changes in dynamic topography. Here, we additionally present the geological evidence associated with dynamic uplift. From 20 My to Present, in the Argentine foreland, a thick paleosol sequence (Dávila et al., 2007; Dávila and Lithgow-Bertelloni, 2014) deposited prior to the arrival of the flat slab within a giant peneplain close to sea level, underwent a progressive surface uplift through more than $500 \mathrm{~km}$ across strike (Fig. 5b). High-gradient fluvial beds developed on top of the paleosols (Dávila et al., 2007), consistent with a relief increase, and direct evidence of the steeper topographic gradients. Today, both sedimentary sequences are found between 0.4 and $1 \mathrm{~km}$ above sea level (Fig. 5b). The paleosurface reconstruction agrees with the trend of dynamic uplift predicted by our model (Fig. 5b red curve) and the expected foreland elevation obtained after subtracting the dynamic contribution (Fig. 3). The differences in magnitude between the paleosurface and our model (between $100 \mathrm{~m}$ and $<1 \mathrm{~km}$ ) likely reflect uncertainties in the reconstructions of the paleosols, which could be on the order of the elevation change and model parameters. For example, the density structure, the lithospheric rigidity along a refrigerated lithosphere (e.g., Collo et al., 2011), or even lateral variations in viscosity, which might reduce the dynamic topography amplitudes. There might also be small contributions to total topography due to crustal thickening $(<<5 \%$ c.f. Jordan et al., 2001; Ramos 2010) and possibly lithospheric thickening (García Castellanos et al., 2002) that we have 
not completely unraveled. We note that we made no effort to optimize viscosity structure or density anomalies to match the data, opting instead, given uncertainties, to focus on trends rather than exact fits. Matches to the amplitudes would likely be fortuitous given uncertainties in data and models. Nonetheless we point out that adding the flexural contribution shown in Fig. 5b would improve the match by a few $100 \mathrm{~m}$. In Peru, unfortunately, the wet climate and dense vegetation have not preserved similar stratigraphic markers to reconstruct the distal foreland paleoelevations. But the arrival of the flat slab coincides with the formation of the Sub-Acre/Solimões basin nearly $1000 \mathrm{~km}$ from the trench and changes in the drainage pattern of the Amazon (Eakin et al., 2014).

Flat subduction: marine transgressions or regional uplift?

Across both flat-slab segments, neither large subsidence episodes nor preserved marine beds have been reported (Hoorn et al., 2010; Ruskin et al., 2011) in the geological literature. The Solimoes formation has been interpreted as having marine facies (c.f. discussion in Eakin et al., 2014), but recent work shows marine incursions only in the northernmost part of the NW South American margin, perhaps the paleo-Orinoco river (Hoorn et al., 2010). Neither does the geology of South America preserve any marine beds associated with ancient episodes of flat subduction (Ramos, 2009). Indeed there are no marine rocks within the interior Andean foreland for the last 350 My (Mpodozis and Ramos, 1989). The sedimentary facies in the Pebas mega-wetland in NW South America does not in itself provide evidence of flooding, connection to the ocean or even of low elevations, rather only of a low gradient paleoenvironment, which can and does occur at high elevations today (Uyuni and Atacama, for example). Stable isotopic analyses also rule out marine facies (Latrubesse et al., 2010). Geological evidence hence support our predictions and are in disagreement with recent studies that show marine flooding for South America during the last 40 to 10 My (Shephard et al., 2010). 
Our results also suggest an alternative interpretation for the topographic evolution of the US Western Interior (Burgess et al., 1997; Liu et al., 2011), which we show schematically in Figure 6. The current favored explanation is that the flat slab acted as a source of negative buoyancy producing extensive, large amplitude down-warping that can explain, to first order, intracontinental marine incursions, the mismatch with eustatic curves (Liu et al., 2008) and the offset between subsidence and flexural curves in several foreland basins (Liu and Nummedal, 2004). This picture has been explored with models based on reconstructions of the extinct Farallon plate, with a flat subduction episode between $~ 65-50 \mathrm{Ma}$ and similar dynamical models to those used in South America (Shephard et al., 2010). In each case, slab flattening is associated with intracontinental, long-wavelength and highamplitude patterns of subsidence (Mitrovica et al., 1989; Burgess et al., 1997; Heller et al., 2003; Liu and Nummedal, 2004; Heine et al., 2008; Liu et al., 2008, 2011; Spasojevic et al., 2009). The models show that the flat slab, assumed to be anomalously cold (dense), is particularly effective at generating negative dynamic topography because it is located at shallow depth. But the modern flat slabs of South America show no marine incursions. The more recent work of Liu et al. (2008), Liu et al. (2011) and those based upon similar simulations (Spasojevic et al., 2009) adjust the effective slab temperature based on matches to borehole data, hence decreasing the amplitude of the subsidence over flat segments.

The "anomalous" subsidence pattern of the Western Interior basins in the US (Liu et al., 2011) may alternatively be explained, on the basis of our model, by the subsidence of the leading edge of the slab, not the flat part, as previously proposed. Taking the Argentine segment as the model, we can infer that the position of the slab leading edge would have been at $111^{\circ} \mathrm{W}$ (Figure), where maximum sedimentary thicknesses are recorded. In turn, the long-wavelength early Cenozoic Laramide unconformity (Cross and Pilger, 1978), usually seen as a problem of preservation (Burgess et al., 1997; Liu et al., 2008), could be alternatively explained by dynamic exhumation. The exhumation is driven by the dynamic uplift generated by slab flattening or lateral variations in dynamic topography 
amplitude due to variations in oceanic crustal thickness or composition in the slab. The thermochronology reported in the Canadian Shield (Flowers, 2009) is consistent with this alternative. The thin gravel sheets and formation of regional discordances widespread in the Western Interior (Heller et al., 2003) might be associated with a progressive and cratonward shifting of the slab flattening, similar to the evolution inferred from paleosols, gravel sheets and modern topography recorded across the Argentine foreland.

\section{Concluding remarks}

Flat subduction and the subduction of ridges and aseismic ridges are pervasive today and through Earth's history (van Hunen et al., 2002; Arrial and Billen, 2013). The correlation between flat segments and subduction of aseismic ridges with thickened oceanic crust in South America bears this out (Gans et al., 2011; Bishop et al., 2013). The presence of thickened crust makes flat segments buoyant or neutrally buoyant (van Hunen et al., 2002; Arrial and Billen, 2013). Thickened crust is the result of higher degrees of partial melting, which result in crust that is drier than average MORB (Langmuir and Forsyth, 2007). This thickened crust at depths of $100 \mathrm{~km}$ under the continent is not only drier but also colder, which hinder the basalt to eclogite transition (van Hunen et al., 2002). Only after that eclogite is formed, would the density of the lithosphere increase significantly, enough to be denser than the surrounding mantle and generate downward flow. The consequences then for slab morphology and density structure are enormous as demonstrated here. When we account for details of the slab shape, age and crustal structure, even at wavelengths of $400-500 \mathrm{~km}$, the pattern and amplitude of dynamic topography induced by the flow is dramatically different (Fig. 2) compared to a homogeneously dipping slab that accounts only for slab age. We feel confident that even greater detail would influenced the pattern and amplitude of dynamic topography above slabs even more. 
If we consider a possible temporal evolution of a slab with homogeneous dipping angles to one with flat and neutrally buoyant segments we can infer that slab flattening drives uplift rather than subsidence, as we demonstrated here using the difference between our Paleogene and Present-day models for South America. Our proposed evolution is in agreement with geological observations over the flat slab segments of Peru (Fitzcarrald Arch) and Argentina (the Sierras Pampeanas) which show uplift. Regional subsidence only occurs much farther away from the trench at the slab leading edge (Dávila and Lithgow-Bertelloni, 2014 and Eakin et al., 2014). We can use the latter to propose a different scenario for the flooding of the US western interior following the Laramide orogeny.

While we acknowledge that our models are simplified and instantaneous they still reveal important physical behavior. They trade rheological sophistication for unprecedented detail in the buoyancy field as revealed by observed slab morphology and density. They do not have continuous time-dependence but show uplift and subsidence trends from different times. Our results imply in fact that buoyancy structure even at wavelengths of $400-500 \mathrm{~km}$ is at least if not more important than rheology. In fact discrepancies between our previous models (diminished buoyancy at the leading edge due to adding global structure) reinforces the notion that morphological and density changes are not merely details but crucial to understanding the surface record of deformation and sedimentation due to mantle dynamics.

In the future our own slab reconstructions, should consider more complex morphologies such as the possibility of flat subduction in the Altiplano and other regions and proposed slab windows in Patagonia. Most progress could be made by combining local and regional highresolution tomography from seismic arrays with seismicity to make synthetic slabs (as in Spasojevic and Gurnis, 2012) to produce the most accurate present-day morphology to be used in conjuction with variational data assimilation. 
Acknowledgments FONCyT, CONICET, and SECyT-UNC (Argentina), the Royal Society and UCL (UK) and the Marie Curie Fellowship IIF Program (ANDYN Project, EU) supported our studies in South America. We are grateful to two anonymous reviewers and the editor whose unusually thorough and constructive reviews improved the quality and clarity of the manuscript substantially. We are also grateful to Nicolas Flament for providing the spatial files of the residual topography models shown here.

\section{Figure captions}

Figure 1. (a) Digital elevation model of South America from (Shuttle Radar Topography Mission SRTM 90) and relevant tectonic features above flat segments (Fitzcarrald Arch and PBF in Perú, Sierras Pampeanas in Argentina), Benioff zone contours at 200 and $600 \mathrm{~km}$ depth (solid black lines). Offshore, we show the trench and Chile ridge (solid black line) and the location of the Nazca and Juan Fernández aseismic ridges (grey bands). We also note the age of the subducting lithosphere at the trench. (bottom inset) Present-day model for the Nazca slab, color-coded by density contrast $\left(\mathrm{kg} / \mathrm{m}^{3}\right)$ baesd on the age of the slab at the time of subduction and for the flat segments the presence of overthickened oceanic crust. The present-day model is based on hypocentral relocations of Gutscher (2002) and magneto-telluric imaging (Booker et al. 2004).

Figure 2. Predicted dynamic topography for the (top left) Present-day and Paleogene (top right) models to degree and order 50. (Middle panel) Profiles of dynamic topography along the flat segments at $13^{\circ}$ (thick dotted line) and $31^{\circ} \mathrm{S}$ (thick solid line) for the Present-day (thick lines) and the Paleogene. (Bottom panel) Illustrative cartoons of the slab geometry and lithospheric structure for the Present-day (left) and the Paleogene (right). We also illustrate the location of the uplifted peneplain (white), and paleosols (light gray) and pericratonic basins (dark gray) for the 
Present-day and the location of deep foreland basins in the Paleogene (dark gray) and peneplain with soils (light gray). The subtraction of the Paleogene from the Present-day dynamic topographies reveals the uplift shown by contours in Figure 3a.

Figure 3. Correlation between dynamic topography and foreland elevations. (a) Positive values of the change of dynamic topography (black contours) match the location of the subducted aseismic ridges (Nazca and Juan Fernandez Ridges in grey), where flat subduction occurs (200-m Benioff contours in red). When the change of dynamic topography is subtracted from the modern elevations of South America (b), the foreland elevations (represented by the Peruvian broken foreland -PBF- and the Fitzcarrald Arch in Peru and the Sierras Pampeanas in Argentina) flatten (c). The pre-flat slab foreland topography (shown in c) is consistent with the formation of the foreland planation surface and paleosol sequences reported in the south-Central Andes literature (see Dávila et al., 2007 and Fig. 5b). Notice that the Present-day regional depressions (darker greens) of the Argentine Pampas and the Northern and Southern Amazon (or Manaus) Basins (Dávila and Lithgow-Bertelloni, 2013; Eakin et al., 2014) (NAB and SAB) develop only where the leading edges of flat-slabs dip again into the mantle. In $\mathrm{C}$ these regions are shown in lighter green (small elevations), which emphasizes the dynamic changes to the topography. The ages in million years (Ma) are the ages of the sea floor at the trench.

Figure 4. Four different global residual lithospheric structure models expanded to degree and order 20. Visual similarities cannot hide the large regional and local differences in amplitude, sign and pattern. (Top left) Flament et al. (2013) removes a constant value of $529 \mathrm{~m}$ from the total topography. (Top right) Naliboff et al. (2012) consider a full lithospheric structure. Upper and lower crustal thicknesses and density from CRUST2.0, depleted mantle thickness 3-6 times the thickness of the lower crust. Densities computed from a self-consistent thermodynamic model of mantle mineralogy. (Bottom left 
and right) Panasyuk and Hager (2000) and Kaban et al. (2003) also consider the full lithospheric structure, but make different assumptions about oceans and continents than TDL.

Figure 5. Residual topography, dynamic topography and uplift history. (a) Comparison between local residual topography models at $31^{\circ} \mathbf{S}$ (green bars) and profiles extracted from global models (blue band is the range of residual topography from the lithospheric structure model of Naliboff et al., (2012) and Flament et al. (2013)). The $0 \mathrm{~km}$ mark is in the High Andes $\left(\sim 71^{\circ} \mathrm{W}\right)$, distances are calculated from this point along a constant line of latitude. The local bars are the High Andes $\left(70^{\circ} \mathrm{W}\right)$, Sierras Pampeanas $\left(67.5^{\circ} \mathrm{W}\right)$ and Pampas $\left(63^{\circ} \mathrm{W}\right)$. Crustal and mantle thickness from Gans et al. 2006 (Figure 6). The bottom of the bar is the residual topography assuming the flat slab offers isostatic support, the top without. See Appendix for further details. We show the present-day predicted dynamic topography with buoyant $\left(10 \mathrm{~kg} / \mathrm{m}^{3}\right)$, neutral $\left(0 \mathrm{~kg} / \mathrm{m}^{3}\right)$ and dense $(-10$ $\mathrm{kg} / \mathrm{m}^{3}$ ) flat segments (black lines) and those predicted from global tomography (red lines). Note that without neutrally buoyant segments the predicted topography lies outside the residual topography estimates. Purely thermal slabs as the topography predicted from shear-wave model S40RTS (Ritsema et al., 2011, see model in Fig. Ap1 in Appendix) (whether one removes 140 or $290 \mathrm{~km}$ of possible chemical signals) induce much too large negative dynamic topography. (b) Comparison of the nontectonic uplift in central Argentina based on the reconstruction of the Argentine Pampean paleosurface (or peneplain) and related paleosols (yellow markers and thick black dashed line) and the predicted dynamic uplift caused by the change from normal to flat subduction (thick red line). The non-tectonic uplift was estimated between the early Miocene and Present based on the reconstruction of Miocene paleosols that were originally deposited near sea level (Dávila et al., 2007) on the Pampean surface, and can be seen today at over $1 \mathrm{~km}$ above sea level. We point out that slab density contrasts and mantle viscosity structures were not adjusted to best fit the amplitudes. 
Figure 6: Reconstruction of the Farallon flat slab (striped area) in North America during the Early Cenozoic (60 Ma) based on our South American models. Note that the Farallon flat-slab leading edge separates foreland areas where subsidence dominates (eastward in grey) from uplift areas (westward from the leading edge).

\section{Bibliography}

Arrial, P-A and Billen, M.I, 2013. Influence of geometry and eclogitization on oceanic plateau subduction. Earth and Planetary Science Letters, 363, 34-43.

Bello, L., Coltice, N., Rolf, T. and Tackley, P.J., 2014. On the predictability limit of convection models of the Earth's mantle, Geochemistry, Geophysics and Geosystems, 15, 2319-2328.

Bishop, B., S. Beck, G. Zandt, A. Kumar, L. Wagner, M. Long, and H. Tavera (2013), Receiver function study of the Peruvian flat-slab region: Initial results from PULSE, AGU Fall Meeting 2013, San Francisco.

Booker, J., Favetto, A. and Pomposiello, M.C., 2004. Low electrical resistivity associated with plunging of the Nazca flat slab beneath Argentina. Nature, 429, 399-403.

Burgess, P.M., Gurnis, M., and Moresi, L.N., 1997. Formation of sequences in the cratonic interior of North America by interaction between mantle, eustatic, and stratigraphic processes. GSA Bull., 108, 1515-1535.

Capitanio, F.A., Faccenna, C., Zlotnik, S., and Stegman, D.R., 2011. Subduction dynamics and the origin of Andean orogeny and the Bolivian orocline. Nature, 480, 83-86.

Cembrano, J.; Lavenu, A.; Yáñez, G.; Riquelme, R.; García, M.; González, G.; Hérail, G., 2007. Neotectonics. In: Moreno, T; Gibbons, W. (eds.), The geology of Chile. The Geological Society, London, 231-261. 
Collo, G., Dávila, F.M., Nóbile, J., Astini, R.A., and Gehrels, G., 2011. Burial and thermal history of the Vinchina foreland basin, W Argentina $\left(28^{\circ}-29^{\circ} \mathrm{SL}\right)$ : Signature of the Neogene flat subduction in the Andes?: Tectonics, 30, TC4012, doi:10.1029/2010TC002841.

Cross, T.A. and Pilger, R.H., Jr., 1978. Tectonic controls of Late Cretaceous sedimentation, Western Interior, USA. Nature, 274, 653-657.

Dávila, F.M. and Lithgow-Bertelloni, C., 2013. Dynamic topography in South America. Journal South American Earth Sciences, 43, 127-144.

Dávila, F.M. and Lithgow-Bertelloni, C., 2014. Reply to comment on "dynamic topography in South America" by Hechenleitnera, Fiorelli, Larrovere, Grellet-Tinnera, and Carignano. Journal South American Earth Sciences, 50, 95-96.

Dávila, F.M., Astini, R.A., Jordan, T.E., Gehrels, G. and Ezpeleta, M., 2007. Miocene forebulge development previous to the broken foreland partitioning in the southern Central Andes, westcentral Argentina. Tectonics, 26, TC5016, doi:10.1029/2007TC002118.

Dávila, F.M., Lithgow-Bertelloni, C., Giménez, M, 2010. Tectonic and dynamic controls on the topography and subsidence of the Argentine Pampas: the role of the flat slab. EPSL, 295, 187194.

Dávila, F.M., Giménez, M., Nóbile, J., Martínez, P., 2012. The evolution of the high-elevated depocenters of the northern Sierras Pampeanas ( $\left.28^{\circ} \mathrm{SL}\right)$, Argentine broken foreland, southCentral Andes: The Pipanaco Basin. Basin Research, doi: 10.1111/j.1365-2117.2011.00539.x.

Devlin, S., B. L. Isacks, M. E. Pritchard, W. D. Barnhart, and R. B. Lohman, 2012. Depths and focal mechanisms of crustal earthquakes in the central Andes determined from teleseismic waveform analysis and InSAR. Tectonics, 31, TC2002, doi:10.1029/2011TC002914.

Eakin, C.M., Lithgow-Bertelloni, C., and Dávila, F.M., 2014. Influence of Peruvian FlatSubduction Dynamics on the Evolution of the Amazon Basin. Earth and Planetary Science Letters, 404, 250-260. 10.1016/j.eps1.2014.07.027 
Espurt, N., Baby, P., Brusset, S., Roddaz, M., Hermoza, W., Regard, V., Antoine, P.-O., Salas-

Gismondi, R., and Bolaños, R., 2007. How does the Nazca Ridge subduction influence the modern Amazonian foreland basin? Geology, 35, 515-518.

Flament, N., Gurnis, M., and Müller, R.D, 2012. A review of observations and models of dynamic topography. Lithosphere, 5, 189-210.

Flowers, R.M., 2009. Exploiting radiation damage control on apatite (U-Th)/He dates in cratonic regions. Earth Planet. Sci. Lett., 277, 148-155, doi:10.1016/j.eps1.2008.10.005.

Gans, C.; Beck, S.; Zandt, G.; Gilbert, H.; Alvarado, P., 2011. Continental and oceanic crustal structure of the Pampean flat slab region, western Argentina, using receiver function analysis: New high-resolution results. Geophysical Journal International, 186, 45-58.

Garzione, C.N., Hoke, G.D., Libarkin, J.C., Withers, S., MacFadden, B., Eiler, J., Ghosh, P. and Mulch, A., 2008. Rise of the Andes. Science, 320, 1304, doi: 10.1126/science.1148615.

Garcia-Castellanos, D., Fernandez, M. and Torne, M., 2002. Modeling the evolution of the Guadalquivir foreland basin (southern Spain). Tectonics, 21: doi 10.1029/2001TC001339.

Giménez, M. Dávila, F.M., Astini, R.A., and Martinez, P., 2011. Interpretación gravimétrica y estructura cortical en la cuenca de General Levalle, Provincia de Córdoba, Argentina. Revista Mexicana de Ciencias Geológicas, 28, 105-117.

Gutscher, M.-A. 2002. Andean subduction styles and their effect on thermal structure and interplate coupling. J. S. American Earth Sc., 15, 3-10.

Heine, C., R. D. Müller, B. Steinberger, T. H. Torsvikb, 2008. Subsidence in intracontinental basins due to dynamic topography. Physics of the Earth and Planetary Interiors, 171, 252-264.

Heller, P.L., Dueker, K. and McMillan, M., 2003. Post-Paleozoic alluvial gravel transport as evidence of continental tilting in the U.S. Cordillera. GSA Bull., 115, 1122-1132.

Hoorn, C.; F.P. Wesselingh, H. ter Steege, M. A. Bermudez, A. Mora, J. Sevink, I. Sanmartín, A. Sanchez-Meseguer, C. L. Anderson, J. Figueiredo, C. Jaramillo, D. Riff, F. R. Negri, H. 
Hooghiemstra, J. Lundberg, T. Stadler, T. Sarkinen, A. Antonelli, 2010. Amazonia through time: Andean uplift, climate change, landscape evolution and biodiversity. Science, 330, 927931.

Jordan, T. E. and Allmendinger, R. W. 1986. The Sierras Pampeanas of Argentina: A modern analogue of Rocky Mountain foreland deformation. American Journal of Science, 286, 737-764.

Kay, S.M. and Mpodozis, C., 2002. Magmatism as a probe to the Neogene shallowing of the Nazca plate beneath the modern Chilean flat-slab. J. S. Am. Earth Sciences, 15, 39-57.

Langmuir, C.H., D.W. Forsyth. 2007. Mantle melting beneath mid-ocean ridges. Oceanography 20(1): 78-89.

Lestunff, Y. and Ricard, Y., 1995. Topography and geoid due to lithospheric mass anomalies. Geophysical journal international, 122, 982-990

Lithgow-Bertelloni, C., and Richards, M.A., 1998. The dynamic of Mesozoic and Cenozoic plate motion. Reviews of Geophysics, 36, p. 27-78.

Lithgow-Bertelloni, C., and Gurnis, M., 1997, Cenozoic subsidence and uplift of continents from time-varying dynamic topography. Geology, 25, 735-738.

Liu, L., S. Spasojević, M. Gurnis, 2008. Reconstructing Farallon plate subduction beneath North America back to the Late Cretaceous. Science, 322, 934-938.

Liu, S. and Nummedal, D., 2004. Late Cretaceous subsidence in Wyoming: Quantifying the dynamic component. Geology, 32, 397-400.

Liu, S., Nummedal, D., and Liu, L., 2011. Migration of dynamic subsidence across the Late Cretaceous United States Western Initerior Basin in response to Farallon plate subduction. Geology, 39, 555-558.

Martinez, M.P. and Gimenez, M.E., 2003. Fuerte anomalía gravimétrica residual positiva en el Sistema de Famatina y su relación con paleosuturas: Explicaciones alternativas. Rev. Asoc. Geol. Argent., 58, 176-186. 
Mitrovica, J.X., Beaumont, C., \& Jarvis, G.T., 1989. Tilting of the continental interior by the dynamical effects of subduction: Tectonics, $\mathbf{8}, 1079-1094$.

Mpodozis, C. and Ramos, V.A., 1989. The Andes of Chile and Argentina. In: Ericksen, G.E., Cañas, M.T. and Reinemund, J. (eds.) Geology of the Andes and its relation to hidrocarbon and mineral resources, Circum-Pacific Council for Energy and Mineral Resources, Earth Sciences Series 11: 59-90.

Naliboff, JB; Lithgow-Bertelloni, C; Ruff, LJ; de Koker, N, 2012. The effects of lithospheric thickness and density structure on Earth's stress field. Geophysical Journal International, 188, 1 - 17. 10.1111/j.1365-246X.2011.05248.x.

Ramos, V.A. 2009. Anatomy and global context of the Andes: Main geologic features and the Andean orogenic cycle. In Kay, S.M., Ramos, V.A. and Dickinson, W. (eds.) Backbone of the Americas: Shallow Subduction, Plateau Uplift, and Ridge and Terrane Collision, GSA Memoir 204, 31-65.

Ritsema, J.; H. J. van Heijst, A. Deuss, and J. H. Woodhouse, 2011. S40RTS: a degree-40 shear velocity model for the mantle from new Rayleigh wave dispersion, teleseismic traveltimes, and normal-mode splitting function measurements. Geophys. J. Int., 184, 1223-1236, doi: 10.1111/j.1365-246X.2010.04884.X.

Ruskin, B.G., Dávila, F.M., Hoke, G.H., Jordan, T.E., Astini, R.A., Alonso, R., 2011. Stable isotope composition of Middle Miocene carbonates of the Frontal Cordillera and Sierras Pampeanas: Did the Paranaense seaway flood western and central Argentina? Palaeogeography, Palaeoclimatology, Palaeoecology, 308, 293-303.

Shephard, G.E., Liu, L., Gurnis, M., Muller, R.D., 2010. Miocene drainage reversal of the Amazon River driven by plate-mantle interaction. Nature Geoscience, 3, 870-875.

Shephard, G.E., Liu, L., Müller, D., Gurnis, M., 2012. Dynamic topography and anomalously negative residual depth of the Argentine Basin. Gondwana Research Letters, 22, 658-663. 
Spasojevic, S., L. Liu, and M. Gurnis, 2009. Adjoint models of mantle convection with seismic, plate motion, and stratigraphic constraints: North America since the Late Cretaceous, Geochem. Geophys. Geosyst., 10, Q05W02, doi:10.1029/2008GC002345.

Steinberger, B., 2007. Effects of latent heat release at phase boundaries on flow in the Earth's mantle, phase boundary topography and dynamic topography at the Earth's surface. Physics of the Earth and Planetary Interiors, 164, 2-20.

van Hunen , J., van den Berg, A. P. and Vlaar, N. J., 2002. On the role of subducting oceanic plateaus in the development of shallow flat subduction. Tectonophysics, 352, 317-333.

Winterbourne, J., Crosby, A. and White, N. J., 2009. Depth, Age and Dynamic Topography of Oceanic Lithosphere beneath Heavily Sedimented Atlantic Margin. Earth and Planetary Science Letters, 287, 137-151.

Woods, M.T. and Okal, E.A., 1994. The structure of the Nazca Ridge and Sala y Gomez seamount chain from the dispersion of Rayleigh waves. Geophysical Journal International, 117, 205-222. 